The Australian Surveyor, Vol. 41, No. 1, 38-52, 1996

\title{
Understanding Cadastral Maps
}

by

Ian Williamson

Professor of Surveying and Land Information,

Department of Geomatics,

The University of Melbourne,

Australia

Chairperson, Commission 7 (Cadastre and Land Management) (1994-8)

International Federation of Surveyors

Tel: $+61-3-93444431$

Fax: +61-3-9347 4128

Email: i.williamson@eng.unimelb.edu.au

and

Stig Enemark,

Reader in Cadastre and Land Management,

Department of Development and Planning,

Aalborg University,

Denmark

Chairperson, Commission 2 (Professional Education) (1994-8),

International Federation of Surveyors

Tel: $+45-98-158522$

fax: $+45-98-156541$

Email: enemark@i4.auc.dk

\section{ABSTRACT}

Cadastral maps are generally regarded as an essential part of the land management infrastructure in most countries yet there is often misunderstanding about their characteristics and role. Due to the vast range of different cadastral systems and resulting cadastral maps, it is very difficult to describe a "typical" cadastral map.

It is the authors' view that it is also very difficult, if not impossible, to understand the characteristics and functions of a cadastral map without understanding the respective cadastral system. As a result this paper endeavours to examine the characteristics and functions of cadastral maps by examining the cadastral mapping systems in Denmark and Australia.

The Danish system is a typical "old world" European system which had its history in land taxation. The Australian systems could be considered "new world" systems which have been more heavily influenced by land market considerations. Even though the Australian and Danish cadastral systems are very similar, understanding the characteristics and functions of cadastral maps in the two systems remains difficult.

This study discusses the different characteristics of cadastral maps which have been designed for different users or functions. In particular the paper concentrates on the issues concerned with developing digital multi-purpose cadastral maps.

The major conclusions from the paper are that the creation and maintenance of multi-purpose digital 
cadastral maps is a difficult and complex task. This complexity arises to a large degree because the characteristics of a cadastral map designed to serve traditional land markets or land registration purposes are quite different from the characteristics of a modern multi-purpose cadastral map.

\section{INTRODUCTION}

Cadastral maps are an important component of land administration in most countries. In many countries they are taken for granted however this paper argues that they are often one of the least understood products from the work of surveyors.

No two cadastral mapping systems are the same, albeit there are a number of basic components in common to most systems. Since cadastral maps are derived in different ways in different jurisdictions, there are many different perceptions as to what constitutes a cadastral map. Due to historical, cultural and social differences, cadastral maps play very different roles in different jurisdictions ranging from being charting or index maps to being the legal determination of parcel boundaries.

In developing countries cadastral surveying and cadastral mapping are often criticised for being slow and expensive, and one of the major limitations on economic development. Yet most authorities would agree that some form of cadastral mapping in developing countries is essential for economic development and environmental management.

In virtually all developed countries, the needs of computerised land and geographic information systems (LIS/GIS) has given urgent impetus to computerising cadastral maps and creating digital cadastral data bases (DCDB). This process is creating many institutional, legal, technical and administrative problems.

This desire to establish DCDBs is being given increased impetus due to a new range of enabling technologies such as satellite position fixing (GPS), improved spatial data collection techniques such as digital theodolites and "soft copy" photogrammetry, as well as a vast range of new information and communications technological tools.

This paper is a result of joint research undertaken by the two authors as a result of their activities in the International Federation of Surveyors. The authors have chosen to use a comparison of the Australian and Danish cadastral mapping systems to give a better understanding of the role of cadastral maps generally. The choice of Australia and Denmark are fortuitous since these countries share very similar cadastral systems with arguably the biggest difference being the development of their cadastral maps. While an analysis of these two systems provides a good insight into cadastral maps generally, the authors recognise that these two systems only represent a relatively small cross-section of cadastral maps used world-wide, albeit an important one.

The Danish system exhibits many of the attributes and history of the classic European or "old world" Napoleonic cadastres, although Denmark was never part of the Napoleonic Empire. It was created to support a comprehensive land valuation and land taxation system and was based on the maps resulting from the enclosure movement common in Europe in the late 18th and early 19th Centuries.

Australia on the other hand exhibits many of the characteristics of a cadastral system established in a newly developed country ( a "new world" system) under the influence of a colonial power. Australia is also important since the Australian Torrens System has arguably had more influence on the establishment of cadastral systems in developing countries over the last century or so than any other system.

The authors acknowledge the extensive list of publications on this and related topics, and refer readers to the selected bibliography for further reference.

\section{DEFINITIONS}

The recent "Statement on the Cadastre" approved by the International Federation of Surveyors (FIG, 
1995) gives a generally accepted definition of the cadastre and the relationship to the cadastral map as follows:

A cadastre is normally a parcel based, and up-to-date land information system containing a record of interests in land (e.g. rights, restrictions and responsibilities). It usually includes a geometric description of land parcels linked to other records describing the nature of the interests, the ownership or control of those interests, and often the value of the parcel and its improvements.

The FIG Statement states that land parcels are defined by formal or informal boundaries marking the extent of lands held for exclusive use by individuals and specific groups of individuals (e.g. families, corporations, and communal groups). Each parcel is given a unique code or parcel identifier, such as an address, a co-ordinates, or a lot number shown on a survey plan or map.

Graphical indices of these parcels, known as cadastral maps, show the relative location of all parcels in a given region. Cadastral maps commonly range from scales of 1:500 to 1:10,000. Large scale diagrams or maps showing more precise parcel dimensions and features (e.g. buildings, irrigation units, etc.) are often prepared by cadastral surveys for each parcel based on ground surveys and aerial photography. Information in the textual or attribute files of the cadastre, such as land value, ownership, or use, can be accessed by these unique parcel codes shown on the cadastral map, thus creating a complete cadastre.

Importantly, cadastral systems are not ends in themselves. Their primary purpose today is to support land tenure systems which protect land rights through public recognition and recording, and support effective land markets which allow land rights to be traded efficiently and effectively. That is they permit land rights to be bought, sold, mortgaged and leased. The success of a cadastral system is a function of how well it achieves these broad social and economic objectives, not the complexity of its legal framework nor the technical sophistication of the cadastral surveys or cadastral map.

\section{THE DEVELOPMENT OF CADASTRAL MAPS IN DENMARK}

The Danish cadastre, which derived from the results of the enclosure movement, was established in the year 1844. From the beginning the cadastre consisted of two parts; the cadastral register and the cadastral maps. Both of these components have been updated continually ever since. The purpose of establishing the cadastre was to levy land taxes based on the yielding capacity of rural properties. Of historical interest the first Danish cadastre was created in 1688, however it lost its value over the years since there were no maps and no provision for updating the register.

As a result of the enclosure movement, the former feudalistic society was changed into a society based on private ownership to land. The necessary maps for implementing this process were surveyed by plane table at the scale of 1:4,000. This basic mapping took place during the last two decades of the eighteenth century. The resulting property framework from the enclosure movement formed the basis for the new cadastral maps. This meant that there were no legal survey measurements defining original property boundaries. Each map normally includes a village and the associated cultivated areas. As a result the maps are "island maps" covering different areas and are not based on any local or national control network (Figure 1). 
The boundaries of the urban parcels in the villages were shown very approximately on the cadastral maps since these urban properties were not important for land valuation purposes. The provincial towns were surveyed separately based on a provision from 1863. The maps were established by traverse surveys, most of them at a scale of 1:800.

The parcels within each village area were numbered and recorded in the cadastral register showing parcel areas, parcel numbers, and the valuation of each property (being an aggregation of all parcels in the property) with the cadastral maps identifying the location of the cadastral parcels. The present cadastral system is still based on these historic village areas which constitute the framework for the register and the cadastral maps.

Even if the primary purpose of the cadastre was to levy land taxes, the cadastral identification was also used to support the land ownership and land transfer system. Even though the cadastre was established in 1844, it has been a requirement in Denmark since 1810 that all subdivisions of land and all changes to parcel boundaries had to be undertaken by private licensed surveyors. Simultaneously, in the year 1845 , the Land Registry System was established by the local district courts for recording and protecting legal rights of ownership, mortgages, easements and leases for land.

The land tenure system was established as follows:

- the cadastral register identifies real properties, which might include more than one land parcel, by cadastral number(s) and area,

- the cadastral map shows all land parcels graphically,

- legal survey measurements are used to precisely identify all new parcel boundaries determined after the initial creation of the maps, and

- the Land Book identifies the legal land rights based on the cadastral identification.

Over time the Danish cadastre has changed from being primarily a basis for land valuation to a legal cadastre supporting a land market. The cadastre is maintained by a state agency, while cadastral surveys are carried out by the private licensed surveyors. 
When land is to be subdivided or parcel boundaries changed, both private or public landowners must apply by law to a private licensed surveyor for the necessary legal surveys and for the preparation of documents needed for submission of an application to the National Survey and Cadastre for updating the cadastre. Government organisations are not permitted to employ their own licensed surveyors to undertake cadastral surveys. The application must contain a copy of the cadastral map showing the alteration of the boundaries, measurement sheets showing the new boundaries, documentation proving legal rights, as well as documentation showing the approval of the future land use according to planning regulations and land use laws.

The approval by the National Survey and Cadastre, showing the updated cadastral register and the updated cadastral map, is returned to the private licensed surveyor. Simultaneously, the approval is forwarded to the municipality for updating the property tax register, and to the local Land Registry Office for updating the Land Book. Deeds or mortgages may then be entered in to the Land Book based using the updated cadastral identification. The local Land Registry Offices do not keep any maps of cadastral parcels. These must be obtained from a local private licensed surveyor or from the office of the National Survey and Cadastre.

The process of determining existing parcel boundaries requires a private licensed surveyor to compare the legal survey information (the cadastral map and the measurement sheets) to the monuments, occupations, fences etc on the ground. If discrepancies are found the surveyor has the responsibility of resolving the problem. In some cases land owners have agreed to move a boundary without legally updating the cadastre, or maybe the boundary in the field has been accepted by the landowners for more than 20 years, in which case there may be a justified claim for a prescriptive right (a claim of adverse possession). In such cases, the licensed surveyor must involve the landowners, however if the landowners cannot agree on the boundary, the matter is resolved through a special legal procedure for determining disputed boundaries undertaken by the licensed surveyor.

In Denmark boundaries are surveyed to a high accuracy in a local sense with corners typically marked with iron pipes. Today most cadastral surveys are connected to state control points and linked into the national geodetic network (since 1934). Danish surveyors use the latest technology for cadastral surveys including digital theodolites, GPS and computerised drafting systems. Within a few years it is expected that regulations will require the submission of all cadastral survey plans to the National Survey and Cadastre office to be in digital form.

Carrying out cadastral surveys in Denmark is the monopoly of licensed surveyors in private practice. Licenses are granted automatically by the Minister of Housing to surveyors who have completed a five year university degree in chartered surveying, and who have worked for a surveyor in private practice for three years. There are about 160 private surveying firms employing about 350 surveyors in Denmark. The duties and responsibilities of licensed surveyors are controlled through the Surveyors Act. Professional matters are the responsibility of the Danish Association of Chartered Surveyors.

Historically the purpose of establishing the cadastre was to collect land taxes based on the productivity of the soil. The cadastre is still used for this purpose but to much smaller extent, since land tax is now based on the market value of the individual properties (since 1903). Today the cadastre has a much broader objective, which is mainly to support an efficient land market, as well as providing a basis for appropriate land management. Today Denmark's cadastre is accepted as providing basic infrastructure for managing economic interests in land as well as supporting environmental and development interests (Enemark, 1992). The interaction between the cadastre and the Land Book operates very efficiently even though the two systems are maintained in different organisations.

The importance of the use of the cadastre to support land management has steadily increased. During the first half of this century the cadastral system served as a basis for managing the regulations under the Agricultural Holdings Act. During the second half of this century the cadastral identification has also become an important component for managing a number of environmental acts. In addition the cadastre 
provides basic information to support many activities including the operation of town and country planning processes, construction planning and implementation, and utility administration.

The last two decades has seen moves to establish a complete computerised cadastral information system to support these growing users. It is accepted that when cadastral information is part of integrated information systems, it can improve the efficiency of the land transfer process as well the overall land management process. In short, the Danish cadastral system has met the challenge of into the modern digital GIS-world (Enemark, 1994).

The cadastral register was computerised from 1984 to 1986 . The register includes 2.5 million parcels representing about 1.5 million properties. The computerisation of the Land Book will be completed before the year 2000. The computerisation of the cadastral maps will also completed before the year 2000 .

The basic function of the cadastral map will still be the same even if the maps are computerised. The benefits will be the multipurpose use of the maps, in combination with other land data registers and maps, leading towards cadastral based GIS-systems. The concept of a modern digital cadastre therefore has to face the challenge of being an effective tool to support the traditional cadastral processes of land transfer and subdivision, as well as being an efficient tool for land management and administration. The challenge will be to use the lowest acceptable standard for fulfilling these objectives in order to minimise the costs of computerisation.

The multi-purpose use of the cadastral map requires in principle graphical consistency with the topographic map. The demand for consistency refers to topographic maps at a scale of 1:1,000 in urban areas and 1:4,000 in rural areas. On the other hand, the historic legal identification of the boundaries must be kept intact even if the cadastral maps are computerised for multi-purpose uses.

The analogue cadastral maps are island maps which are not related to the national grid. Over time they have become distorted due to shrinkage, redrawing and updating procedures. Just digitising the analogue maps will not result in a multi-purpose map.

Furthermore, the cadastral maps have certain legal significance for identifying registered boundaries where there are no cadastral surveys, eg old boundaries in rural areas and villages. The cadastral map, in these cases, will constitute the legal basis for determination of any changes to the registered boundaries and the connected property rights. Adjusting the registered cadastral boundaries to match features on topographic maps may therefore lead to some arbitrary and unacceptable changes in the registered legal rights.

Recognising these problems, and accepting that the cost of computerisation of the cadastral maps must be reasonable, this computerisation process is undertaken in two stages:

- State control points and cadastral surveys connected to the national grid form a "skeleton" cadastral map. In urban areas about $40 \%$ of boundary points are entered in this way and in rural areas about $20 \%$.

- The remaining parcels are inserted in the map by digitising the remaining parts of the analog cadastral maps and fitting these to the "skeleton map" by transformation. Identified elements in the digital topographic map are also used to control the transformation of the analog maps.

By using this approach the accuracy of the boundary coordinates may vary considerably, ranging from a few centimetres in some urban areas to several metres in some rural areas. Therefore, the digital cadastral map does not totally match the existing digital topographic map. It must be considered that the nature and origin of those two kinds of maps are fundamentally different.

It must also be noted that the digital cadastral map is a graphic map, not a numeric map (Figure 2). This means that the coordinates of the boundary points only represent the boundary in the graphic map. The final determination of boundaries has to be done according to cadastral regulations. The parcel 
coordinates in the DCDB therefore may not be used for the exact calculation of parcel areas and dimensions (Enemark, 1987).

The procedures for updating the digital cadastral map or DCDB will be the opposite to the procedure for updating the analog map. In the analog map new boundaries were adjusted graphically to the position of existing mapped boundaries. In the digital cadastral map any new cadastral measurements will be used for adjusting the position of the existing boundaries. This will establish a process of continual improvement of the accuracy of the DCDB. It is however recognised that some problems may arise in practice when a decision has to be made on the area to be included in this adjustment. Furthermore, adjustment of existing boundaries in the DCDB may cause problems in those cases where other administrative boundaries or features were based on cadastral boundaries in a Geographical Information System. These problems of updating and upgrading the DCDB will continue to be investigated so that sustainable solutions can be developed to suit all users.

The Danish National Survey and Cadastre office believes a understanding of the problems related to the process of establishing and maintaining the digital cadastral map are essential for all users. In other words the success of the digital cadastral map will depend on the degree of educated use of the map.

\section{THE DEVELOPMENT OF CADASTRAL MAPS IN AUSTRALIA}

As with the Danish system, an understanding of the development of the wider Australian cadastral system is necessary in order to understand the development of Australian cadastral maps. First it must be recognised that land administration in Australia is a state or territory responsibility, therefore there are eight separate Torrens systems of title registration in Australia, and eight separate cadastral surveying and mapping systems, albeit there are significant similarities between them.

The Australian cadastral systems derive many of their principles and concepts from English Common Law. They have married the system of land transfer under English Common Law with the needs of a vast developing country. As a result, land registration systems (Torrens systems), cadastral surveying systems and a land surveying profession have developed, which to a large degree, are unique to Australia. 
The Australian cadastral systems are derived from individual surveys of individual parcels for individual owners in support of a land market system where land rights can be bought, sold, mortgaged and leased (Williamson, 1983). They were not derived from a complete cadastral record of all land parcels as shown on a cadastral map having its genesis in a land taxation and valuation system, which is the case with most European systems. As a result the systems did not commence with a cadastral map. Even though all original grants of land were charted on often uncontrolled or partially controlled small scale grant maps called Parish and County maps, these maps have not influenced the development of cadastral maps significantly since they only record historic ownership patterns. Typically these maps were at too small a scale and did not show current parcel patterns resulting from subdivisions of alienated lands, to become the basis of state cadastral mapping systems.

In summary, Australian cadastral systems are designed specifically to support the land market and the individual land owner. They were not designed as part of a wider land administration system albeit they have increasingly developed such a role.

At the time of settlement by the English colonists in 1788, Australia was considered a vast unsettled and unexplored continent. The country was however fully settled by the indigenous Aboriginal peoples who had divided the country into many regions each under the jurisdiction of a clan group. It was not until 1993 that the Australia Federal Government first acknowledged the historical right of the indigenous peoples to land ownership. As a result the development of Australian cadastral systems has not been influenced by the land tenure systems or patterns of Australia's indigenous peoples.

For about the first seventy years of Australian settlement, all land transfers were carried out using the English system of Deeds Registration called the "Old System". It was not until the mid 1850s that Robert Torrens introduced his now famous system in South Australia to simplify land transfer, which had become expensive, complicated and inefficient. The system quickly spread to all the Australian colonies (now states or territories), although several states still have significant remnants of the "Old System".

At the time of settlement the second most important person in most colonies was the Surveyor General who was responsible for alienating and managing all land in the colony. Alienation of land continued unabated in Australia through the 19th Century and well into the 20th Century with the result that dual land title and land survey systems grew up in all the Australian states. On the one hand there were the systems which controlled the management, leasing and alienation of Crown lands, usually under the responsibility of the state or territory Surveyor General. It was the office of the Surveyor General which maintained the Parish and County maps. The Surveyors General were historically not concerned with land once it was alienated from the Crown, however that has changed significantly since many are responsible for updating their state cadastral map which shows all government and private lands. In parallel with this were the systems to manage the land ownership records concerned with the private alienated lands, which were typically the responsibility of the Registrars General within the state or territory Land Titles Offices. Each of these systems managed land records and had its own survey system and regulations, one relating to Crown lands and the other relating to alienated private lands.

Prior to the Second World War and particularly afterwards, alienation of lands reduced significantly while at the same time the activity of the Land Titles Offices increased with the subdivision of already alienated private lands and the consequent growth of the land market. The result has also seen a change in the traditional role of the Surveyors General around Australia with them becoming increasingly involved with the management of the spatial information system in their respective state or territory.

Today's cadastral maps had their genesis in the systems to manage the land ownership records concerned with the private alienated lands. For the first century or so since the introduction of the Torrens systems, subdivisions of private lands were charted on index maps which had a very low spatially integrity (Figure 3 ). The integrity of the cadastral system was primarily based on the accurate individual cadastral surveys and plans. All these charting or index maps and cadastral survey plans were controlled and managed by the state Land Titles Offices. 
Interestingly many of the cadastral maps which were the basis of the index maps in the state Land Titles Offices, were prepared by valuation offices which maintained their own cadastral mapping sections, as did most cities, local government organisations and many utilities. Often these maps were not kept up-todate, usually only covered part of each state and usually had a low integrity since they did not have a legal purpose. As a result, such maps were used in state Land Titles Offices where possible for charting, but for nothing more. They did not have sufficient coverage or integrity to be used as the basis of each state's cadastral map. Late in the last century several cities did establish very accurate large scale topographic maps similar to the English large scale topographic maps, but unfortunately these maps were not kept up-to-date although they do provide a valuable historic record (Williamson, 1983)

Due to the difficulties in undertaking surveys in this vast harsh country and the rapid settlement that occurred, especially after the gold rushes of the late 19th Century, settlement often preceded survey, even though the actual alienation of land was always based on a cadastral survey. These circumstances resulted in the development of the "isolated" cadastral survey system. As a result cadastral surveying in Australia has never been a part of a state-wide cadastral mapping process although in the last decade or so, with the establishment of cadastral maps, these processes are coming closer together. Cadastral surveys of individual land parcels are carried out to a high mathematical precision and are usually only connected into neighbouring land parcels. The surveys are usually not based on state coordinate systems.

Boundaries are surveyed to a high accuracy in a local sense and corners are typically marked with wooden pegs with reference marks usually buried adjacent to corners or created in adjacent occupations such as concrete kerbs or walls. Each cadastral survey is usually connected into one or more Permanent Survey Marks which tend to be concrete blocks or marks in concrete kerbs which are integrated over time into each state coordinate system.

Today's cadastral system is basically a title registration system supported by isolated cadastral surveys of individual parcels. Land titles and cadastral survey plans are kept in the same centralised Land Titles Offices. The land titles are increasingly in computer form and do not include a diagram of the parcel in their digital form. As in the European systems, the title refers to a parcel number in the isolated cadastral survey plan (not a cadastral map) which created the parcel. Computerised indexes have been established which relate land titles to cadastral plans, street address, and to other identifiers used by utilities, land 
taxation, local government etc.

Since the Land Titles Offices were only concerned with supporting land market processes, such as land transfer and subdivision of land, there was no imperative to develop a cadastral survey system based on a state coordinate system or to develop a cadastral mapping system. As a result isolated cadastral surveys continue to this day since they adequately serve the demands of a land market. All cadastral survey plans are checked and filed in Land Titles Offices. Historically a record of all cadastral surveys has been maintained on index or charting maps.

Australian cadastral surveyors use similar technology to their Danish colleagues in undertaking cadastral surveys and preparing cadastral plans. Today some states permit cadastral plans to be submitted to the state Land Titles Offices in digital form thereby facilitating the updating of the state digital cadastral data bases.

The practice of cadastral surveying in each state or territory is undertaken by licensed or registered land surveyors and is controlled by a state Surveyors Act with associated regulations. These acts specify the duties and responsibilities of registered cadastral surveyors, the regulation of them in undertaking cadastral surveys, the role of Boards of Surveyors and the requirements to become a registered Surveyor. Professional matters are the responsibility of the Institution of Surveyors, Australia Inc.

The educational requirements in Australia are similar to Denmark however the requirements for registration in Australia is significantly more complex and more time consuming.

The last two decades has seen moves to establish complete computerised cadastral maps (Figure 4) in support of land management, utility management, land administration and local government administration. This has necessitated projects to provide a unique parcel identifier for every land parcel in every state. These developments have been driven to a large degree by the automation of land records and the establishment of digital land, facility and geographic information systems.

The typical techniques in establishing these computerised cadastral maps have usually been to fit the best available cadastral survey plans together on to a topographic base map using control surveys, fence lines, 
physical features, road boundaries etc as control using a graphic "rubber sheeting" approach. This is particularly the process used in rural areas based on scales of 1:10-50,000. The resulting cadastral map is then digitised and the DCDB established.

In urban areas, field control is used to a greater extent with typical scales usually 1:1-4,000. Most computerised cadastral maps in urban areas were initially prepared by authorities responsible for water, sewerage and drainage in response to their requirement of digital maps to manage all their services.

The result is that cadastral maps in Australia represent boundaries to a graphical accuracy. While large variations in the accuracy of the graphical coordinates of boundaries are possible in some areas, the accuracy of the scaled boundary coordinates in most state systems is about $\pm 1 \mathrm{~mm}$ at map scale $( \pm 2.5 \mathrm{~m}$ at 1:2,500). One exception is the DCDB in the Australian Capital Territory which has been established by ground survey measurements based on the Territory's coordinate system (Williamson and Rainbird, 1986).

Now that complete digital cadastral data bases have been completed across Australia, states are fully appreciating the difficulties of updating and upgrading DCDBs (Wan and Williamson, 1994a, 1994b, 1995a, 1995b). Another major change is that there has been a move from these systems being "provider" driven, primarily by surveyors, to being "user" driven. As DCDBs become increasingly important, their administration is moving to state land or geographic information centres which are sometimes separated institutionally from the responsibilities of surveyors or spatial information specialists. However the control of cadastral surveys still rests with state Surveyors Boards. This splitting of the institutional responsibility of cadastral surveys and cadastral maps, and in some states also title registration, is of concern.

The above administrative and institutional trends are in response to the establishment of state-wide and national spatial data infrastructure systems and micro-economic reform. They have caught some surveyors by surprise. Regarding the future, the only thing which is certain about Australian spatial information structures is that they will continue to change as the information society continues to mature.

\section{CADASTRES DEVELOPED FROM A LAND TAX VERSUS A LAND MARKET PERSPECTIVE}

Denmark is a good example of a European cadastral system which was established as a basis for land valuation and land taxation. As a result European cadastres include a land use component to facilitate land valuation. It was generally later and almost always separately that European cadastral systems developed a legal title or deeds registration system to support a land market thereby facilitating the sale, purchase, mortgage and lease of land rights. It was an obvious step for the European title and deeds registries to adopt the unique identifier for each land parcel from the existing cadastre.

In Europe, the cadastral map was an integral component of the cadastre, not the title or deeds registries. Even today most European title or deeds registries are completely separate organisations to the cadastral organisation and often do not even have a copy of the cadastral maps. The organisations are usually in different ministries. It is the responsibility of the state cadastral office to keep the cadastral map and automated cadastral register up-to-date. The Land Book, which is kept in the Land Registry Offices, uses the cadastral identification for all land parcels. Since these offices keep no cadastral maps, all reference to maps and cadastral survey plans must be to the state cadastral office or a local licensed surveyor.

The Danish cadastral maps have been established for two centuries and have some legal significance regarding boundary definition. This is in stark contrast to Australian cadastral maps which have been developed over the past decade or so and play no role in boundary definition.

Since most properties were taxed, the establishment of cadastres in Europe was a systematic process. Such a process requires or at least is very much facilitated by the use of a cadastral map. Since land taxation is a government function, the establishment and maintenance of the cadastre and the associated cadastral maps has always been funded by government. 
Over the last century, European cadastral systems have been increasingly dominated by land market pressures rather than land tax considerations. This has resulted in the computerisation of title records to improve efficiency and a merging or coming closer together of the cadastre and title or deeds registry activities. However the trend has not usually been as rapid as has occurred in Australia since the European systems are decentralised and work well in an analogue form.

The Australian cadastral systems were created from the opposite direction to the European systems. From the beginning they were driven by land market considerations and were very much "user pays" systems. As a result there was no justification to create an accurate cadastral map - simply land markets in their purest form do not require cadastral maps to operate (although without maps they can be very expensive to operate). It could be argued that the historic Parish and County grant maps in Australia were Australia's original cadastral maps however for the reasons stated above they did not develop into today's cadastral maps.

On the other hand cadastral systems designed to support land markets only, do require a system of cadastral surveying to uniquely describe land rights spatially. This results in cadastral plans of individual parcels or groups of parcels. The "isolated" survey system in Australia was the result. This meant that owners of land rights were both secure in their ownership as well as being able to trade their land rights reasonably efficiently. Most authorities would argue however that the operation of a cadastral system not based on a cadastral map is expensive on the land owner in the short term and the government in the long term.

From the perspective of cost, equity, efficiency and multi-purpose use, it is generally accepted that the best cadastral system is that based on the systematic determination of land rights based on a state wide cadastral mapping system.

An important difference between the Australian and European systems are that Australian systems are centralised whereas the European systems are usually decentralised. As a result Australian Land Titles Offices are very large organisations holding enormous quantities of records compared to their European counterparts. This has been one of the reasons why there has been a greater urgency to computerise Australian title records.

Another reason why Australian cadastral systems did not require cadastral maps is that land markets, by their very nature, are only concerned with individual transactions, whereas land valuation and land tax systems require a systematic approach. Therefore there was no necessity in Australia for systematic surveys resulting in complete cadastral maps. Also by the time Australia was fully settled the emphasis on land taxation as a major source of government revenue had waned and as a result there was no incentive to develop a European style cadastre. Also the determination of land value for taxation purposes moved away from a land productivity basis to a market value, an approach which usually does not require an accurate cadastral map.

Since the Australian cadastral systems did not require cadastral maps in the European sense, it has only been in the last decade or so that most Australian states and territories have justified the compilation of state-wide cadastral maps from these isolated surveys. The justification has been to reduce duplication for a variety of others users such as valuation or land tax authorities, local government and utilities, and to facilitate the use of land and geographic information systems.

An analysis of the Australian, Danish and other systems highlights the important benefit of having the land registration system, and the cadastral survey and mapping system managed by the same organisation. When these two basic components are together administratively, each system fully appreciates the importance and inter-dependency of the other. When they are separated there is sometimes a dangerous view that a Land Book or land registration system can operate without the support of a complete and upto-date cadastral survey and mapping system. 
The objective of the next two sections is to show that the attributes or characteristics of the spatial component within the Australian and Danish cadastral systems, which are designed to serve the land market or land registration function, are quite different from the attributes of multi-purpose cadastral maps, particularly in their digital form.

In Australia and Denmark there are five major attributes or characteristics of cadastral maps and a sixth related characteristic concerned with the required accuracy of supporting cadastral surveys. These can be used to distinguish cadastral maps designed for different functions as shown in Table 1, and discussed below:

1. Accuracy of the cadastral map. The spatial accuracy and integrity of cadastral maps can vary a great deal as shown by the reviews of the Danish and Australian cadastral systems. Cadastral maps can be graphic out-of-date approximations of the cadastral framework which are used primarily for charting of cadastral surveys or for valuation and land tax purposes, as originally used in Australia. On the other hand some cadastral maps are created by field surveys and in their digital form are as accurate as the supporting cadastral surveys, as seen in the cadastral maps of the Australian Capital Territory (Williamson and Rainbird, 1986). In Denmark the original cadastral maps were graphical (plane table) island maps based on a local origin, while the more modern digital maps are based on the state geodetic control network and use accurate field survey techniques.

Another aspect affecting accuracy arises from whether the map is compiled by or from systematic surveys as is usually the case in Denmark or sporadic cadastral surveys as in Australia. If the map is compiled from sporadic cadastral surveys, the map will usually have a lower integrity and a greater variability of accuracy in the spatial location of parcel boundaries.

2. Completeness of the map. This relates to whether the map is up-to-date. For example charting maps and many cadastral maps used for local government or valuation were historically never kept up-todate in Australia. The integrity of the system was always in the very accurate cadastral surveys and supporting plans. However in the Danish system all cadastral maps are kept up-to-date by the national cadastral office.

3. Digital requirement. Some map functions in Denmark and Australia, such as for land markets and land registration, do not require a computerised cadastral map while other uses such as for automated mapping/facility management (AM/FM) systems used in utility management do require a computerised map.

4. Requirement for other spatial detail . At the most simple level the cadastral map shows legal boundaries of land parcels, some non cadastral detail such as road names and a unique identifier relating each parcel to the title or cadastral indexes. Most Australian and Danish cadastral maps add the reference number of underlying cadastral survey plans and serve a dual role as a charting map. When cadastral maps are used in a more multi-purpose role, and especially for urban and rural land management, a greater amount of topographic detail is required. For urban purposes a greater amount of technical detail, such as buildings, kerbs and street furniture is shown on the large scale maps, although contours are usually not shown. In rural areas more traditional topographic information is shown, including contours.

5. Role in boundary determination. Danish cadastral maps have legal significance. However Australian cadastral maps play no role in boundary determination at all, unless the cadastral map has been established from all the coordinates determined by field surveys. This is the case for much of the cadastral system in the Australian Capital Territory.

6. Accuracy of supporting cadastral surveys . Cadastral maps designed for title registration in Australia require accurate cadastral surveys to support the function however the supporting index or charting maps do not require to be updated by accurate surveys. Fully updated cadastral maps, such as in Denmark, also require accurate cadastral surveys to secure land rights. Other cadastral maps serving as base for AM/FM functions for example, do require to be updated by accurate cadastral surveys. 
It does not matter what form of land rights are identified by a cadastral parcel and shown on a cadastral map. The parcels can show individual or communal land rights, responsibilities or restrictions. There are numerous examples of this in Australia and Denmark, such as Strata or Community titles.

Charting or index maps are a very common form of cadastral map and are found historically in Australia, but also in North America and many other countries. They are traditionally of a low integrity, are often not related to any coordinate system and are only updated with new charting information such as a new cadastral survey plan number. These maps usually can not be related to topographic maps. The integrity of the cadastral system comes from the accurate isolated cadastral surveys and resulting cadastral survey plans. These cadastral surveys are not based on a national coordinate system. This approach is the traditional basis of the Torrens system.

Current Australian cadastral systems adopt a reasonably accurate digital cadastral map, used for graphic purposes only, which has been compiled by fitting the isolated cadastral surveys together onto the topographic mapping series. Where ever possible cadastral boundaries will be shifted slightly to agree with topographic data. As a result the cadastral maps can be related to the topographic map series thereby facilitating LIS/GIS, particularly if the maps are digital. New cadastral surveys are used to update and upgrade the digital map, although this can cause greater changes in the surrounding cadastral boundaries than in the Danish case. The important aspect about this form of cadastral map is that it can be used for many purposes since the cadastral map generally agrees with the scale topographic map.

The Danish island cadastral map is the most common form historically. This type of map is particularly common in Europe, but was also adopted in many other countries such as New Zealand, Malaysia, Thailand, Korea, Hawaii to name a few. Many of these systems were established using plane table techniques. The systems have relied on accurate cadastral surveys, sometimes based on a coordinate system with a local origin to update the cadastral map. In this case the cadastral surveys have precedence over the cadastral map, but in some cases, such as in Denmark, the cadastral map also has some legal significance. As mentioned this latter case presents particular problems in computerising the cadastral map.

The perceived classic cadastral mapping system is found in Switzerland, parts of Germany and the Australian Capital Territory for example where the accurate large scale cadastral map is upgraded by accurate cadastral surveys based on the state or national coordinate system. In these cases the "legal" cadastral map is underpinned by a "technical" map showing all the coordinates and dimensions.

\section{DIFFERENT FUNCTIONS OF CADASTRAL MAPS}

The specifications of cadastral maps are usually influenced more by the requirements of land markets and land registration than any other use. However the requirements of other users of cadastral maps are sometimes in conflict with these land market requirements. If a multi-purpose cadastral map is to be established and maintained, and this is to be done through the cadastral or land registration process, then a good appreciation of the requirements of these other users is important, as discussed below.

Table 1 shows the different characteristics of cadastral maps designed to suit different users or functions in Australia and Denmark. The map attributes or characteristics in the table are similar to those discussed in the previous section.

The map attributes shown in the Table are considered to be appropriate for the single map functions identified. For example the attributes for "Land Markets" recognise that a cadastral system designed purely for land markets does not need anything more than an approximate index map to chart cadastral survey plans, such as in the Australian cases. However in this case the land market requires accurate cadastral surveys to operate.

The categorisation also does not recognise that in many cases, functions are combined in many 
jurisdictions. For example in many cities "Utilities" and "Urban Management" are combined.

While it is recognised that many people will have different views on the ranking of the map attributes (high, medium or low) for the different map functions, the major objective of this analysis has been to show that a multi-purpose digital cadastral map has quite different characteristics to a cadastral map designed to support a land market or land registration system.

1. Requirements of land markets and land registration As stated previously, land markets in Australia and Denmark do not usually require an accurate cadastral map to operate. Land registration requires each parcel to be uniquely defined spatially so that land owners are secure in their rights and can trade those land rights. By its nature land markets operate in a sporadic manner and as such do not demand a systematic inventory of land parcels. Land markets also operate on "user pays" principles and as such there is little financial justification to invest heavily in cadastral maps. However it is generally considered that a cadastral system based on an accurate cadastral map will be more efficient and less expensive than a system with a charting or index map. In countries which do not use an accurate cadastral map (such as Australia historically) or countries which have efficient and effective manual cadastral maps (such as Denmark) there is little justification for computerising the cadastral map and creating a DCDB from a land market perspective.

Due to the development of the Danish cadastral system, the cadastral maps have some legal significance. This means the accuracy of the Danish cadastral map in general is required to be of a higher standard initially than the new Australian cadastral maps.

2. Requirements for land tax and land valuation The levying of land taxes requires a systematic inventory of land parcels since all or most parcels must be included in the system. This is also a government function and as such is government funded. The raising of revenue by governments using land taxation has reduced in importance over the last century and has been replaced by personal income taxation and in more recent times by value added taxation (VAT), as in Denmark. Therefore the emphasis on land taxation and the systems which support it have reduced. In addition the basis of land tax has moved from being based on the productivity of the land, as was the case historically in Denmark, to that based on market value of the property. Combining the reduced emphasis on land taxation with the inherent low accuracy required of cadastral maps for land taxation, results in a system where the only real requirement is that every parcel is shown and that the system is kept up-to-date. This is especially the case when annual land taxes are levied, with a result that often such systems are only updated every three or four years.

3. Requirement for utilities management Utilities are generally only interested in managing their infrastructure and in serving their customers. In an ideal world they do not have a requirement for accurate cadastral maps since they are more interested in specific topographic detail such as roads, kerbs and buildings. They do not require all the detail normally shown on topographic maps, especially contours. However where accurate up-to-date topographic maps are not available, which is the case in Australia and many countries, an accurate and systematic cadastral map is required.

In general there are a number of approaches used by utility companies in managing their distribution systems. Utilities providing water, sewerage and drainage systems require accurate maps since the lines are usually shown in an absolute sense in space while other systems such as telephone or cable TV systems often use more diagrammatic maps with cables related to boundaries by approximate offsets. The systems requiring accurate maps locate their lines either absolutely by coordinates or relative to a physical feature or a parcel boundary or in combination.

Increasingly utilities are managing their facilities using digital mapping systems and GIS and as such require a digital map. These systems are often referred to as AM/FM systems (Automated Mapping/Facilities Management). This need is causing utilities to increasingly require more accurate larger scale maps and to show their facilities absolutely. As a result only the "absolute position" has been used in the table since it has most impact on the design of the cadastral map. 
4. Requirement for urban land management Urban areas or cities require a complete record of all land parcels to manage the land use, infrastructure and assets, and to control development in their areas of responsibility. These requirements demand a relatively high accuracy for individual parcels. This is because the cadastral maps must be able to overlay the large scale topographic maps having a high degree of technical detail (not contours). Furthermore the system should be complete and upto-date. This is generally the Australian and Danish experience.

Denmark on the other hand cannot adjust its cadastral boundaries with the same flexibility as Australia because of the map's legal significance and therefore requires a higher accuracy in its digital cadastral map to reduce the apparent errors or mismatching between the cadastral and topographic maps.

5. Requirement for rural land management Different countries have different land management requirements. In Denmark and other European countries the cadastre plays a central role in land management both in urban and rural areas. Many other government organisations also use the cadastral map for land management and environmental management purposes. In rural areas knowledge of the ownership rights is also important. However the topographic map (including contours) is just as important or more important than the cadastral map for land management.

There is an increasing trend to undertake GIS type analyses for land management purposes which means that the cadastral and topographic maps need to be overlayed and match. As a result Denmark requires a relatively higher accuracy of cadastral map in rural areas than Australia.

In summary there are different requirements of a cadastral map from different users. A multi-purpose map which meets the needs of all these users would have to meet all their technical requirements.

Obviously the establishment and maintenance of such a large scale multi-purpose map in digital form is very expensive and difficult to justify, even for the most developed country, however it is the direction that large scale digital mapping is heading. The big question in creating such a system is who will pay to establish the digital map and who will maintain it. The trend to have the DCDB and the digital topographic map on the same coordinate network so that they can be overlayed easily, is causing these two functions to be undertaken by one organisation controlling the cadastre and topographic mapping.

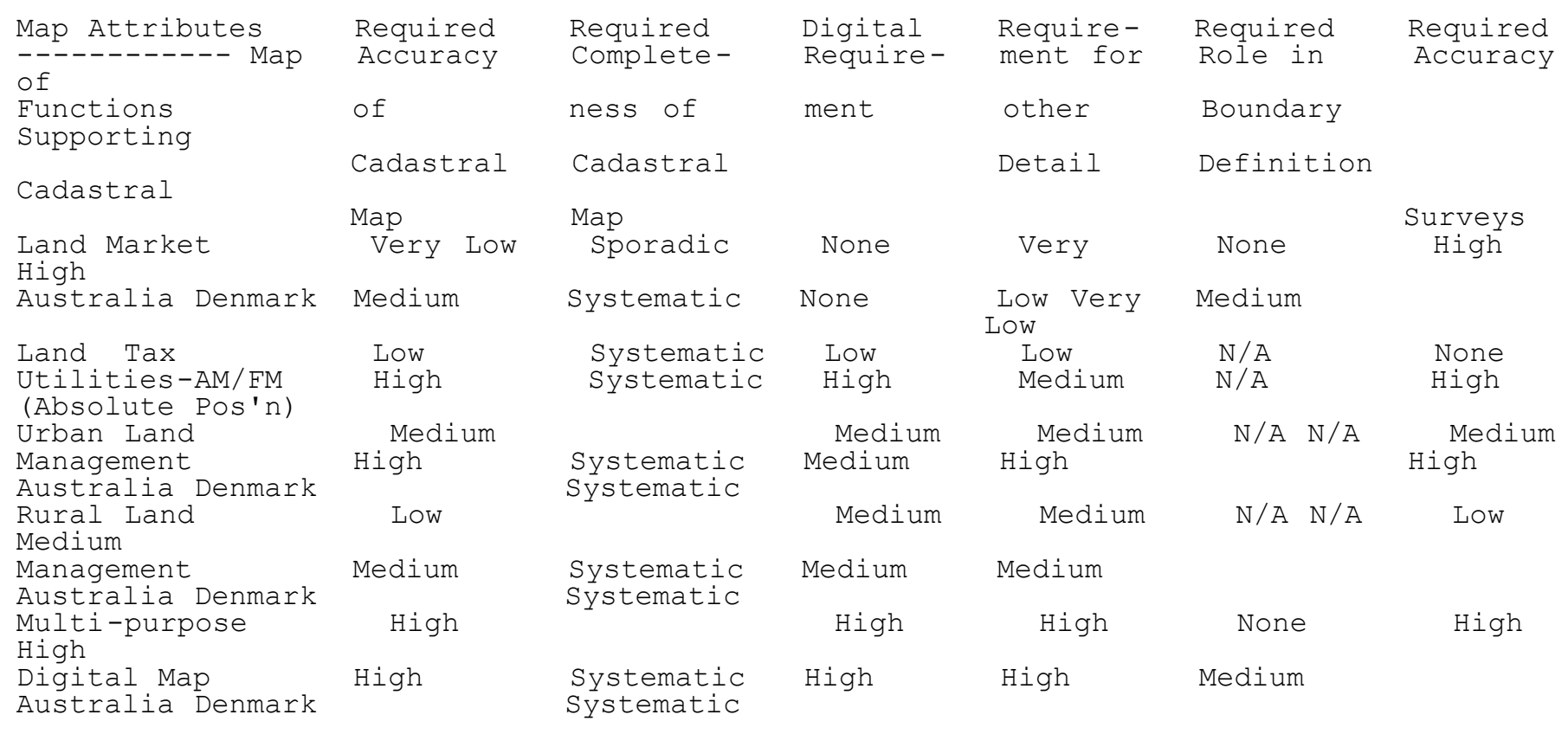

\section{TABLE 1}




\section{ATTRIBUTES OF DIFFERENT CADASTRAL MAPS}

\section{IN AUSTRALIA AND DENMARK}

\section{COMPUTERISATION OF CADASTRAL MAPS}

The justification for computerising cadastral maps includes the following:

- the reduction of duplication in maintaining a cadastral base for many users,

- as a result of converting maps from one scale to another. In Australia's case from Imperial to metric system, and

- to bring the cadastral map onto the same coordinate and mapping system as large scale topographic maps, thereby facilitating LIS/GIS applications.

An important issue in establishing a DCDB is that computerisation of the cadastral maps in general cannot be justified for land registration or land market reasons. Therefore computerisation of the map requires the support of other users both financially and institutionally.

The review of the establishment of computerised cadastral maps in Australia and Denmark also shows that a different approach is required for the computerisation of a cadastral map depending on whether the map is being created for the first time such as in Australia or an existing cadastral map is being computerised, such as in European cadastres. In this latter case the existing cadastral maps have some legal status, therefore greater care must be exercised when the digital cadastral map is created to ensure that the "legal" boundaries or the geometric structure are not distorted significantly. In such cases legislation often limits any change to a boundary on a map without the support of legal processes.

In establishing and maintaining a DCDB there are also a whole range of other technical, institutional and financial issues to be addressed.

At the technical level there are many issues concerned with the method of establishing the DCDB, but more importantly the major issues concern the updating and upgrading of the central data base, and the resulting relationship to the customers in maintaining their own data bases. Communications technologies then become very important. This then raises issues of associativity between the state cadastral layer and the spatial data that the users have related to their copy of the state DCDB. Obviously there is an issue if the state updates or upgrades the DCDB and changes the location of cadastral boundaries, even by a small amount.

At the institutional level, there is an issue of who is responsible for maintaining the DCDB and distributing the updates. Obviously it is necessary for one organisation to administer the DCDB although there are various models using both government and the private sector to maintain the system.

Financial considerations are complex and is an ongoing area of international debate in computerising cadastral and topographic maps. There are issues of who owns the DCDB. The private surveying sector is increasingly responsible for providing the data to update the DCDB yet they are charged if they want to access it. Local government plays an important role and could play an even greater role in updating the DCDB, at least with a proposed development layer. Should they pay to access the system? The overriding issue is how much should be charged for DCDB data. If too high a price is charged then organisations will often try to develop their own system, usually with disastrous results. If too low a price is charged the system may not be maintained, yet a low price ensures the development of an active spatial information market place.

One thing is certain. If the system is not maintained there is no justification for establishing it in the first place.

\section{CONCLUSION}


This review has highlighted the significant differences between cadastral maps in different systems, by using Australia and Denmark as case studies. These differences are due to historical development, legal controls, technological sophistication, institutional structures, economic aspects and the needs of the different users. As a result it is difficult to claim that there is such a thing as a typical cadastral map, although all cadastral maps have some common elements.

The paper highlights two major groups of cadastral maps. First those cadastral maps derived from land taxation systems where the cadastral map was an integral component. This is particularly the case for Denmark and most other European systems. In these cases the cadastre was established first and the title register established later as a separate entity based on the cadastral identification of the parcels.

The second group of cadastral maps were derived from isolated cadastral surveys that were created to support land markets and land registration systems, usually quite recently. This is the case in Australia. In this case it is difficult to justify a cadastral map solely to support a land registration system, other than for cadastral charting.

Due to the focus on the need for efficient land markets, both the European and Australian systems are coming closer together. The European systems are moving from their historic focus on land tax and are bringing their cadastral and land registry offices closer together. The European systems have always had a multi-purpose role which is expanding due to LIS/GIS demands. The Australian systems are also moving to a multi-purpose role and are establishing cadastral maps which are closely linked to the title registration systems. Both these systems are being driven by a need to reduce duplication and a need to develop digital systems in support of LIS/GIS.

Computerisation of cadastral maps is often a controversial issue. Since title registration systems or land markets do not require digital cadastral maps to operate, the responsible organisations often do not wish to move in this direction. However it is often the land registration systems which control or have significant political influence over the cadastral survey and mapping systems. In such cases there is sometimes conflict because the cadastral mapping authority wishes to develop a digital system in response to external pressure from other users.

This review has also highlighted the complexity of this issue since a cadastral map designed for land registration purposes has important characteristics which differ from a cadastral map designed for a more multi-purpose role. Institutional, management and financial issues are obvious results of this dichotomy.

The reality is that computerisation of cadastral maps to meet multi-purpose users is not a simple task, even in the most technologically advanced society. One of the biggest issues is the integration of the cadastral mapping system with the state topographic mapping system. In many cases this means remapping the state cadastre completely as has occurred in several countries!

In summary this paper has highlighted that there are a lot of issues concerned with cadastral maps, and particularly their computerisation, which are often misunderstood and are confusing. The one issue which is certain is that cadastral maps are essential in a modern society, yet their establishment, particularly in digital form, is difficult and complex.

\section{REFERENCES AND SELECTED BIBLIOGRAPHY}

Binns, B.O., 1953. Cadastral surveys and records of rights in land. FAO Land Tenure Series 1. Updated by P.F.Dale, 1994. Food and Agricultural Organisation of the United Nations, Rome.

Dale, Peter, 1976. Cadastral Surveys within the Commonwealth. HMSO, London.

Dale, Peter and McLaughlin, John, 1988. Land Information Management. Oxford: Oxford University Press. 
Enemark, S., 1987. Legal aspects by introducing a dynamic Digital cadastral Map in Denmark. OEEPE, Proceedings of the Workshop on Cadastral Renovation, Lausanne, pp 21-32.

Enemark, S., 1992. Land use planning strategies - towards comprehensive environmental control. Proceedings of the FIG Seminar on Land Use Decision Making. Madrid, pp 345-356.

Enemark, S., 1994. Evaluation of the Cadastral Reform in Denmark - Training the old lady for the skateboard. Proceedings of Commission 7, XX Congress of the International Federation of Surveyors, Melbourne, 703.3/1-11.

Henssen, Johan L.G., 1990. Cadastre, Indispensable for Development. Enschede: International Institute for Aerospace Survey and Earth Sciences (ITC).

International Federation of Surveyors, 1995. Statement on the Cadastre. Canberra, Australia.

Larsson, Gerhard 1991. Land Registration and Cadastral Systems. New York: Longman Scientific and Technical.

Nichols, Sue, 1993. Land Registration: Managing Information for Land Administration. Technical Report \#168, Dept. of Geodesy and Geomatics Engineering, University of New Brunswick, Canada.

Simpson, S. Rowton, 1976. Land Law and Registration. London: Surveyors Publications.

United Nations 1973. Report of the Ad Hoc Group of Experts on Cadastral Surveying and Mapping. New York.

United Nations 1985. Conventional and Digital Cadastral Mapping. Report of the Meeting of the Ad Hoc Group of experts on Cadastral Surveying and Land Information Systems. Economic and Social Council E/CONF.77/L.1.

Wan, W.Y. and Williamson, I.P., 1994a. Problems in Maintaining Associativity in LIS with Particular Reference to the Needs of the Utility Industry. The Australian Surveyor, Vol. 39, No. 3, 187-193.

Wan, W.Y. and Williamson, I.P., 1994b. Solutions to Maintaining Associativity in LIS with Particular Reference to the Needs of the Utility Industry. The Australian Surveyor, Vol. 39, No. 4, 290-297.

Wan, W.Y. and Williamson, I.P., 1995a. A Review of the Digital Cadastral Databases in Australia and New Zealand. The Australian Surveyor, Vol. 40, No. 1, 41-52.

Wan, W.Y. and Williamson, I.P., 1995b. The Users' View of Digital Cadastral Databases in Australia. The Australian Surveyor, Vol. 40, No. 1, 53-62.

Williamson, I.P., 1983. A Modern Cadastre for New South Wales. UNISURV S-23, School of Surveying, The University of New South Wales, 250p.

Williamson, I.P. and Rainbird, B., 1986. The Australian Capital Territory Cadastral Survey and Mapping System. The Australian Surveyor, Vol 33, No 4, 306-326. 


\section{University Library}

\section{- M M I E E R VA A gateway to Melbourne's research publications}

Minerva Access is the Institutional Repository of The University of Melbourne

Author/s:

WILLIAMSON, IAN;ENEMARK, STIG

Title:

Understanding cadastral maps

Date:

1996

Citation:

Williamson, I., \& Enemark, S. (1996). Understanding cadastral maps. The Australian Surveyor, 41(1), 38-52.

Publication Status:

Published

Persistent Link:

http://hdl.handle.net/11343/34005 